\title{
A beszélgetőmüsorokban megjelenő kézi gesztusok leírásának egy lehetséges módja
}

\author{
Szabó Éva \\ MTA-DE-SZTE Elméleti Nyelvészeti Kutatócsoport \\ SZTE Nyelvtudományi Doktori Iskola \\ Béres Tamara \\ SZTE Általános Nyelvészeti Tanszék \\ Guba Csenge \\ SZTE Általános Nyelvészeti Tanszék
}

\begin{abstract}
Összefoglaló
Tanulmányunk fő célja, hogy bemutassunk egy olyan multimodális annotációs keretet, amely a multimodális korpuszok vizsgálatára alkalmas mind a beszéd, mind a kézi gesztusok szintjén, emellett a beszéd és a kézi gesztusok között fennálló szemantikai kapcsolatot is leírja. A dolgozat első felében az annotációs keretet ismertetjük, amelynek alapjául McNeill (1992), Kendon (2004) gesztusdefiníciója, illetve Alibali és társai (2001), Kong és társai (2015) gesztusszemantikai taxonómiája szolgál. A beszéd átírásához Jefferson (2004) konverzációelemzési átírási konvencióját követjük. A dolgozat második felében egy politikai vitaműsorokból álló korpuszon végzett, verbális agresszióra fókuszáló esetelemzéssel ismertetjük a multimodális annotációs keret alkalmazhatóságát.
\end{abstract}

Kulcsszavak: nem verbális kommunikáció, kézi gesztusok, multimodális elemzés, verbális agresszió

\section{Bevezetés}

Az utóbbi évek nyelvhasználati kutatásai a verbális kommunikációval egyidejüleg megvalósuló nem verbális kommunikáció és a nem verbális jelek feltárására is törekednek. Ezen vizsgálódások a pragmatika és a diskurzuselemzés mellett mind az ember-gép kommunikáció (Esposito et al. 2011; Hunyadi et al. 2012), mind a neurolingvisztika (Fasola et al. 2020), mind a pszichológia (Ramseyer-Tschacher 2010) tárgyköreit érintik, tehát a multimodális kommunikáció leírása interdiszciplináris szemléletet követel.

A tanulmány elsődleges célja az, hogy különböző modellek ötvözésével bemutasson egy olyan automatikus eszközt, amely a multimodális korpuszokban - elsösorban beszélgetőműsorokban - megjelenő kézi gesztusok és a beszéd közötti kapcsolat vizsgálatára alkalmas. A dolgozat második felében a bemutatott eljárás tesztelése valósul meg három politikai vitaműsorból álló korpusz alapján.

A dolgozatunk a következőképpen épül fel. Először körüljárjuk a nem verbális kommunikáció definícióját, funkcióját és a verbális és nem verbális kommunikáció kapcsolatát (2. rész). Ezt követően bemutatjuk a gesztus mint nem verbális jel tulajdonságait (3. rész), majd a gesztusok annotálásához szükséges szempontokat (4. 
rész). Továbbá bemutatjuk az általunk létrehozott multimodális sémát (5. rész), a korpuszunk alapján egy esetelemzésben megvizsgáljuk a beszéd és a gesztusok közötti kapcsolatot (6. rész), végül összegezzük az annotációs séma tulajdonságait (7. rész).

\section{A nem verbális kommunikáció}

Az emberi kommunikáció kutatása rendkívül összetett feladat, mivel mind a verbális kommunikáció, mind a nem verbális kommunikáció - kölcsönösen kiegészítve vagy felváltva egymást - az üzenetek kódolásával és dekódolásával jár, habár nem szükségszerű maga a kódhasználat (Németh T. 1989).

Az emberi interakció során az üzenetek átadásának jelentősebb része nem verbális úton történik, Brook és Servatka (2016) szerint a nem verbális jelenségek (cues) a kommunikáció kétharmadát teszik ki. Matsumoto és társai (2013: 4) a nem verbális kommunikációt a következőképpen definiálják: „a nem verbális kommunikáció üzenetek átadása és átvétele bármilyen és minden modalitásban, ami nem tartalmaz szavakat". ${ }^{1}$ A nem verbális kommunikáció a viselkedés azon aspektusára vonatkozik, amely interakciók és személyközi kapcsolatok létrehozására és fenntartására szolgál (Kendon-Sebeok-Umiker-Sebeok 1981: 3). A nem verbális jelek (vagy kódok) közé tartozik többek közt a tekintet, a szemkontaktus, a mimika, a testbeszéd, az érintés, a személyközi távolság, a kézi gesztus, illetve a paralingvisztikai jelek (hangerő, tempó, intonáció) is (Matsumoto-Frank-Hwang 2013; Kostić-Chadee 2015; Hogg-Vaughan 2018: 613-622). A nem verbális jelek által a kommunikációs partner érzelmeiről, attitüdjeiről és interperszonális szerepeiről is gyüjthetünk információt (Ekman-Friesen 1981: 58), viszont mindemellett még számos más céllal és funkcióval is bírhatnak.

Patterson (1983; 1994) szerint a nem verbális viselkedés által (1) információgyűjtést hajthatunk végre a partner érzelmeiről és szándékairól, (2) az interakciót szabályozhatjuk, (3) bizalmasságot, közvetlenséget fejezhetünk ki, (4) dominanciát vagy kontrollt alapozhatunk meg, (5) a céljaink elérését előmozdíthatjuk, (6) a metakommunikációt létrehozhatjuk, (7) benyomást kelthetünk és formálhatunk. Patterson a funkciókra fókuszál, az említett hét funkció leírásában viszont hiányzik a szándékosság és a tudatosság leírása, mivel az (1) esetében a kommunikációs partner érzelmeit nem feltétlen szándékosan és tudatosan teszi nyilvánvalóvá, noha a testtartásából, tekintetéből, arckifejezéséből következtetéseket vonhatunk le. Példaként említendő Ekman (1971) kutatása az alapérzelmekről és azok felismeréséről a mimika által. A (3) és a (4) esetében is előfordul, hogy a kommunikációs partner nem verbális viselkedése nem szándékos és/vagy tudatos, hanem kulturális beágyazottságú, példaként tekintsünk az arab kultúrára, ahol a proxemika (személyek között betartott távolság) jelentősen eltér az angolszász kultúrától (Hall 1963). Emiatt a nem verbális kommunikáció elkülönítendő a nem verbális viselkedéstől. Habár mindkét jelenség informatív, az elöbbi esetében a kommunikatív szándék is jelen van (Ekman-Friesen 1981).

A verbális és a nem verbális kommunikáció szoros kapcsolatban állnak egymással, Ekman és Friesen (1981) hat lehetséges kapcsolatot (egyúttal funkciót)

1 "nonverbal communication as the transfer and exchange of messages in any and all modalities that do not involve words." 
fogalmaznak meg, amelyek a következők: (1) a nem verbális kommunikáció helyettesíti a verbális kommunikációt, (2) a nem verbális kommunikáció megismétli a verbálisat, (3) a nem verbális kommunikáció ellentétben áll a verbálissal, (4) a nem verbális kommunikáció kiegészíti a verbálisat, (5) a nem verbális kommunikáció nyomatékosítja a verbális üzenetet és (6) a nem verbális kommunikáció szabályozza a verbális kommunikációt.

\section{A kézi gesztus}

A gesztus a nem verbális jelek egyike, elsősorban a kéz és a kar koordinált mozdulataira vonatkozik (McNeill 1992; Kendon 2000; Matsumoto-Frank-Hwang 2013). A gesztusok használata egyénenként és kultúránként is változatosságot mutat, illetve a gesztusok kutatásával egyúttal a mentális folyamatokba nyerünk betekintést (Kirk-Burton 1981; Alibali-Heath-Myers 2001; McNeill 2013).

A gesztusok temporálisan, szemantikailag és pragmatikailag kapcsolódnak a beszédhez (McNeill 1992; 2005; Kita-Özyürek 2003). Egyes megközelítések szerint a gesztusok a szóbeli megnyilatkozások szintaktikai szerkezetével is kapcsolatban állnak, mivel igei és főnévi frázisok esetében gyakrabban megjelennek (MüllerLadewig-Bressem 2013: 65).

A gesztusok funkciójának meghatározása a szakirodalomban nem egységes, viszont négy alapvető funkcióban egyetértenek a szerzők. A gesztusok (1) mentális állapotokat, érzelmeket, attitűdöket fejeznek ki, (2) a beszéd és a diskurzus koherenciájának megteremtésére szolgálnak, (3) konkrét és absztrakt referensek kijelölését, azonosítását hajtják végre, vagy (4) a beszélő általuk a saját viselkedését összehangolja a partnerével a társas interakcióban (McNeill 1992; Kendon 2004).

A gesztusok a formájuk és funkciójuk alapján többféleképpen kategorizálhatók. Alibali és társai (2001) megkülönböztetik a reprezentális, ábrázoló funkcióval bíró gesztusokat és a ritmikus ütemezést tanúsító gesztusokat. Ezzel szemben Kong és társai (2015: 100-101) a szemantikai funkció szerint hat formát jelölnek meg McNeill (1992), Ekman-Friesen (1981) és Mather (2005) alapján, amelyek a következők: (1) ikonikus gesztusok (a beszélő egy tárgyat vagy egy eseményt formál a gesztussal), (2) metaforikus gesztusok (a beszélő a gesztus által egy olyan képi tartalmat jelenít meg, amely segítségével egy absztrakt gondolatot akar kifejezni), (3) deiktikus gesztusok (az interlokútor a térben elérhető tárgyra, személyre rámutat), (4) emblémák (nyelv- és kultúraspecifikus gesztusok), (5) kézzel való ütemezés/beat (az ujj, a kéz, a kar ritmikus mozgását jelöli) és (6) azonosítatlan gesztusok.

Az eddigiekből láthatjuk, hogy a gesztusok formai, funkcionális változatosságot mutatnak. A formai és a funkcionális jelleg kölcsönösen hatnak egymásra, mivel a formából fakadóan eltérő funkcióval bír egy gesztus, és fordítva, ezt a kölcsönhatást pedig a mentális folyamatok és a beszéd egyaránt meghatározzák. A kutatásban a gesztusok fizikai jellemzői mellett az adott gesztusegységhez funkciókat rendelünk a beszéd szemantikai tartalma alapján. A gesztusok rendszerezésében célszerünek tekintjük Alibali és társai (2001) elkülönítését, miszerint megkülönböztethetünk reprezentatív és ütemező gesztusokat, viszont a reprezentatív kategóriát túl tág kategóriának tartjuk. Noha Kong és társai (2015) taxonómiája szélesebb spektrumon mozog, a szerzők nem tekintik külön szempontnak a beszéd és a kézi gesztusok között fennálló szemantikai viszonyt, illetve a taxonómiájuk alapján azon esetek 
jelöletlenek maradnak, melyekben a beszélő nem gesztikulál, e testhelyzetet állapotként kezeljük a kézi gesztusokra vonatkozóan. E taxonómiák módosítása alapján a gesztusokat négy fő csoportba soroljuk: (1) reprezentatív, (2) ütemezést tanúsító, (3) állapot és (4) azonosítatlan gesztusok. A reprezentatív gesztusok csoportjában elkülönítjük (1a) az ikonikus, (1b) a deiktikus és (1c) az emblematikus gesztusokat. Most pedig térjünk rá a gesztusok annotálásához szükséges formai jellemzőkre és a létrehozott annotációs keretre!

\section{A gesztusok annotálása}

A multimodális annotáció mind a verbális, mind a nem verbális jelek kódolására és elemzésére szolgál, amelyeket egymástól elválasztva, különböző szinteken elemeznek a kutatók. A nem verbális jelek (fizikai szinten való) vizsgálatakor elkülönítve rögzítik az arckifejezéseket, a tekintetet, a fej mozdulatait, a kézformát, a testtartást, illetve ezen aspektusok még a kutatás céljának megfelelően tovább bővíthetőek, például a szemöldök, a tekintetmintázatok vagy a vállmozdulatok kategóriáinak bevezetésével (Abuczki 2011: 122; Blache et al. 2010; Tóth 2011).

A magyar nyelvű multimodális korpuszok egyike, a HuComTech-korpusz az emberi kommunikáció azon jellemzőinek feltárását tűzte ki céljául a Hunyadi-modell alapján, melyek az ember-gép kommunikáció kutatása számára elengedhetetlenek (Hunyadi 2011a: 8; 2011b). A HuComTech-korpusz terjedelme 50 óra, a résztvevők egyetemi hallgatók (121 fő) voltak, akik egy formális (szimulált állásinterjú) és egy informális interjún vettek részt. A HuComTech-korpuszban audió- és videóannotáció valósult meg, az utóbbi három szinten, melyek a következők: (1) alapszint (kommunikáció), (2) fizikai szint (arckifejezések, tekintet, szemöldök, fejmozgás, kézfej, érintés, testtartás, deiktikus), (3) funkcionális szint (érzelmek, emblémák) (Abuczki 2011: 122). Abuczki (2011: 136-137) a multimodális elemzésében feltárja, hogy intenzív gesztushasználat jelentkezik új információközlés során, a kézi gesztikuláció előhívás markereként és a logikai struktúra jelzéseként funkcionál, illetve a forduló átadása nem jár kézi gesztikulációval. Noha a HuComTechkorpusz a nem verbális jelek többségét jelölte, a kézi gesztusok esetében a kézfej formájára összpontosít, viszont háttérbe szorul a kezek térbeli mozgásának és a beszélő környezete kihasználásának vizsgálata a gesztikuláció szempontjából. Továbbá a HuComTech-korpuszban a fizikai szinten megvalósított videóannotáció nem terjed ki a kézi gesztikuláció összes aspektusára. Az általunk felvázolt annotációs keret a kézi gesztusokra fókuszál, annak komplex leírására törekszik. Az annotációs keret segítségével lehetővé válik egy-egy gesztus jegyeinek meghatározása, amellyel különböző gesztusok azonosítása megvalósulhat.

Mivel a gesztusok a beszéd gyakori kísérői, illetve a beszéd során a gesztusok váltakoznak, ezért a különböző gesztusokat egységekre (gesture unit) lehet bontani (1980). Egy gesztusegység alatt elsősorban a statikus testhelyzet/fázis és a következő statikus testhelyzet/fázis közötti szakasz értendő (Kendon 1980), ugyanakkor előfordul, hogy kettő vagy több eltérő gesztus váltakozik statikus testhelyzet/fázis megjelenése nélkül, így elkülöníthető egy gesztusegység a dinamikus fázisok váltakozásakor is (Seyfeddinipur 2006: 105). Kendon (1980) a gesztusok felépítését vizsgálva a gesztusegységekhez frázisstruktúrákat rendel, amelyek a következők: (1) nyugalmi helyzet (rest position), (2) előkészület (preparation), (3) 
csúcspont (stroke), (4) tartás (hold), (5) visszahúzás (retraction) és (6) részleges visszahúzás (partial retraction) (Ladewig-Bressem 2013: 1061-1062).

A gesztusegységek és frázisok meghatározását követően a kar és a kéz mozdulatait a forma alapján több szempontból lehetséges leírni. A gesztus formája szerint a kézfej alakja (handshape), a tenyér iránya (orientation), a kéz/kar helyzete a térben (position), a mozgás típusa (movement type), iránya (movement direction) és minősége (movement quality) vizsgálható (Bressem 2013; Bressem-Ladewig-Müller 2013).

A kézfej formája elsősorban az ujjak kombinációjára vonatkozik. Az ujjak felvehetik az ökölformát (fist), viszont elkülöníthető a kinyújtott ujjak (flat hand) formája, a két ujj kombinációja (combination of fingers), például az amerikai „OK” jel, vagy egy ujj - főként a mutató- vagy hüvelykujj - helyzete (single finger). A tenyér iránya egyúttal a csukló irányát is jelöli, így a csukló/tenyér pozícióját tekintve megkülönböztethető négy föirány: a fel (palm up), a le (palm down), a vertikális (palm vertical) és a laterális (palm lateral). A kar/kéz helyzete, valamint a gesztus megvalósulásának helye a testhez viszonyítva megtörténhet centrálisan (central), jobb (right) és bal (left) oldalt, lent (upper) és fent (lower), továbbá felső jobb (upper right) és bal (upper left), és alsó jobb (lower right) és bal (lower left) oldalt (McNeill 1992). A mozgás típusa két részre bontható, szabályozottra (+restricted) és szabályozatlanra (-restricted), az előbbi a csukló egyirányú, szabályos mozgását, az utóbbi a csukló szabályozatlan, körkörös mozgását jelöli. A mozgás iránya, amely vonatkozhat a kézfej vagy az egész kar mozgásának térbeli irányára, a vertikális (vertical axis), a laterális (lateral axis) és a sagitális (sagittal axis) tengelyeken vizsgálandó. A mozgás minősége szerint maga a mozgás nagysága, a tempója és az áramlása/folyamata is leírhatóak (Bressem 2013; Bressem-Ladewig-Müller 2013).

Ahogy az előző részben említettük, a multimodális elemzés során a kutatók a beszéd és a nem verbális jelek annotálására törekednek, amelyeket egymástól elkülönítve valósítanak meg. A dolgozat a gesztusok annotálására szűkíti a nem verbális jelek vizsgálatát. Az annotációs eszközök közül az ELAN (EUDICO Linguistic Annotator) (ELAN 2019) szoftvert alkalmazzuk, amely audió- és videófájlok vizsgálatára egyaránt alkalmas, mindemellett felhasználóbarát, mivel a kutatás céljának megfelelően formálható a felület, a sorok (tier) száma korlátlan, így az összes vizsgált szempontot lehetséges jelölni egy-egy annotációs fájlban.

A gesztusok és a beszéd esetében az annotálást célszerü először hang nélkül véghezvinni, elkerülve azt, hogy a beszéd tartalma befolyásolja a gesztusegységek meghatározását, mivel előfordul, hogy egy-egy gesztusegység nincs teljes átfedésben a beszéd formai és tartalmi egységeivel. Kezdjük az annotációs keret leírását a gesztusok tulajdonságaival!

A létrehozott elemezendő multimédiás korpusz politikai vitaműsorokat tartalmaz. A műfaj választását az motiválta egyfelől, hogy többrésztvevős társalgásokat elemezzünk, másfelől a vitaműsorok résztvevői már hozzászoktak a kamera jelenlétéhez, viselkedésük feltehetően természetesebb, továbbá a kompetitív nyelvi viselkedés során megjelenő gesztusok vizsgálata lehetővé válik. Ezenkívül a korpuszunkban olyan videórészletek szerepelnek, melyekben a résztvevők verbálisan agresszívak, illetve hevesebb érzelmeket tanúsítanak ${ }^{2}$, mivel kevésbé törekednek

${ }^{2}$ A kétfajta műfaj (interjú, politikai vitaműsor) tanulságai a későbbiekben összevethetőek lennének. 
egymás arculatának védelmére, illetve a résztvevők közötti szociális távolság és a hatalmi viszonyok kevésbé fontosak.

A vitaműsor a beszélgetőműsorok müfajának egyik típusa, félintézményesített diskurzusnak tekintendő (Ilie 2001). A vitaműsorok helyszínét és annak térbeli tulajdonságait a vitaműsor készítői határozzák meg. A résztvevők elsősorban kör alakú asztalnál vagy félkörben helyezkednek el, amely hatással bír a gesztusok formájára és a tér kihasználására is. Ezt figyelembe véve létrehoztunk egy olyan annotációs sémát, amely a beszélgetőműsorokban megjelenő gesztusok leírására alkalmas keretnek tekinthető.

A gesztusok szegmentálása a gesztusegységig terjed, mivel a séma létrehozásával egy-egy gesztus azonosítására, nem pedig struktúrájának leírására törekedtünk. Egy gesztusegységnek két statikus helyzet közötti szakaszt tekintettünk Kendon (1980) alapján.

Most térjünk át az általunk létrehozott gesztusannotálási sémára!

\section{Annotációs keret a beszélgetőmüsorok multimodális elemzésére}

\subsection{A gesztusok leírására alkalmas annotációs séma}

Egy gesztus jegyeinek meghatározásakor elsősorban Bressem (2013) és Bressem és társai (2013) szempontrendszerét követtük, így külön kategóriákként kezeljük a kézfej formáját, a tenyér/csukló irányát, a gesztus térbeli helyzetét, a mozgás irányát, a mozgás minőségét és a mozgás típusát, viszont egyes jegyeket mellőztünk, illetve további jegyeket hozzáadtunk. Bevezettünk további szempontokat és kategóriákat is, amelyek a következők: (1) a gesztus megvalósulása a környezeti jegyek tükrében (Environment) és (2) a gesztus során alkalmazott kezek (Number of hands) száma. Most pedig térjünk rá a kategóriák leírására!

A) A kézfej formájának tekintetében a következő kategóriákat határoztuk meg:

\begin{tabular}{c|c} 
Handshape & Kézfej formájának tulajdonságai \\
\hline Fist & Ököl \\
\hline Flat hand & $\begin{array}{c}\text { „Lapos tenyér”, } \\
\text { kinyújtott ujjak szorosan egymáshoz kapcsolódva }\end{array}$ \\
\hline Flat hand opened fingers & $\begin{array}{c}\text { "Lapos tenyér”, kinyújtott ujjak egymáshoz kevésbé } \\
\text { szorosan kapcsolódva }\end{array}$ \\
\hline Single finger & $\begin{array}{r}\text { Egy ujj a gesztus középpontjában } \\
\text { (mutatóujj vagy hüvelykujj) }\end{array}$ \\
\hline Combination of fingers & $\begin{array}{c}\text { Ujjak kombinációja, } \\
\text { Céldául a mutató- és hüvelykujj egymáshoz ér }\end{array}$ \\
\hline Clasping hands & Összekulcsolt kezek \\
\hline Touching palms & Egymást érintő tenyerek
\end{tabular}

1. táblázat

A kézfej formái 


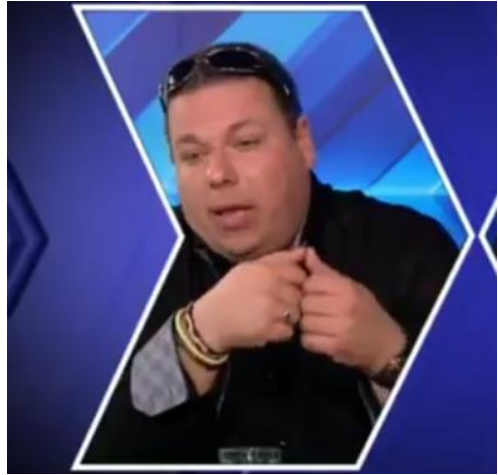

1. ábra

Fist

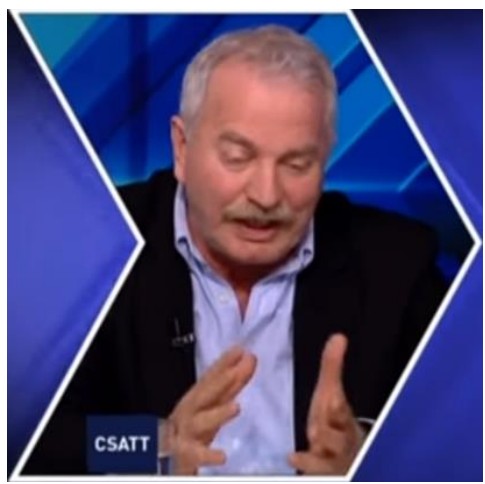

3. ábra

Flat hand opened fingers

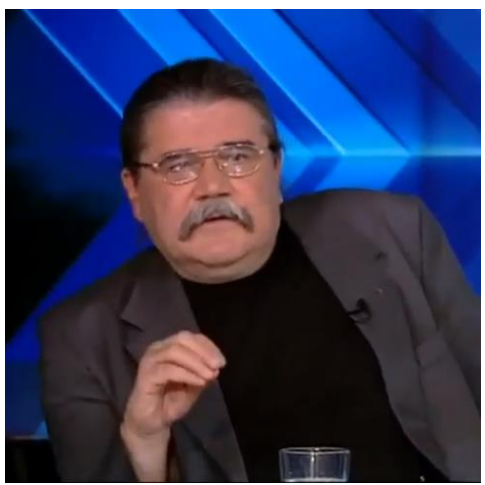

5. ábra

Combination of fingers

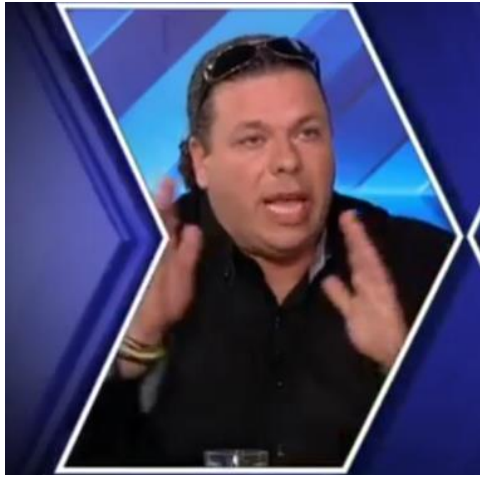

2. ábra

Flat hand

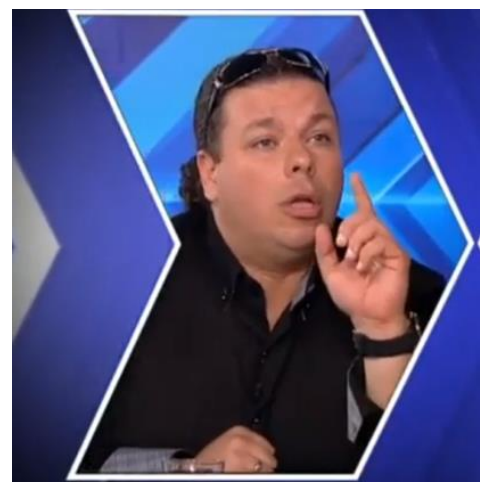

4. ábra

Single fingers

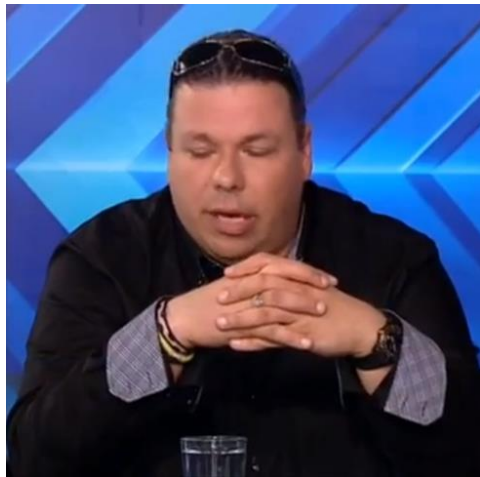

6. ábra

Clasping palms 


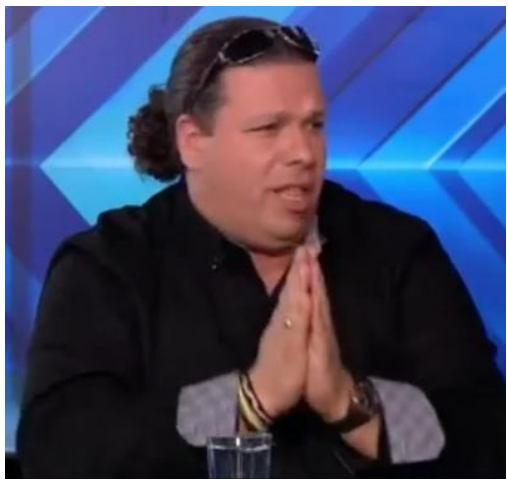

7. ábra

Touching palms

B) A tenyér és csukló irányának meghatározásában Bressem (2013), illetve Bressem és társai (2013) kategóriát követtük, amelyek a következők:

\begin{tabular}{c|c} 
Orientation & A kézi gesztus irányultsága \\
\hline Palm up & A tenyér és a csukló felfelé mutat \\
\hline Palm down & A tenyér és a csukló lefelé mutat \\
\hline Palm lateral & $\begin{array}{c}\text { A tenyér és a csukló vízszintes helyzetben vannak, } \\
\text { tehát a csukló derékszögben áll az asztalhoz képest }\end{array}$ \\
\hline Palm vertical & $\begin{array}{c}\text { A tenyér és a csukló függőleges helyzetben vannak, } \\
\text { tehát az ujjak „felfelé mutatnak” }\end{array}$ \\
\hline
\end{tabular}

2. táblázat

A tenyér és a csukló iránya

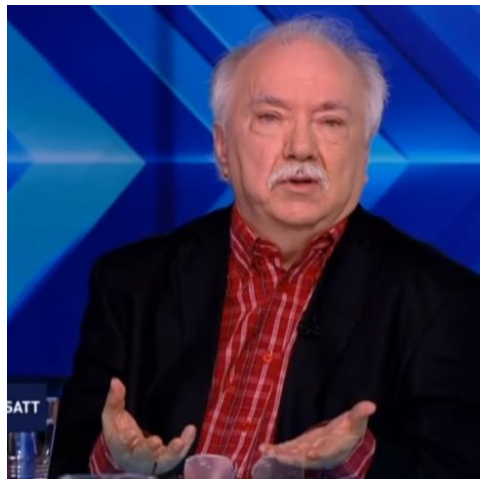

8. ábra

Palm up

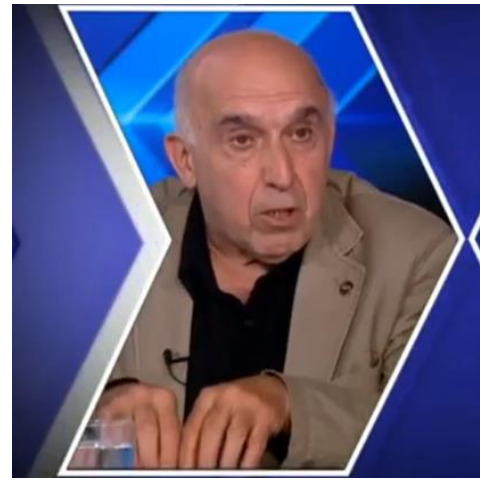

9. ábra

Palm down 


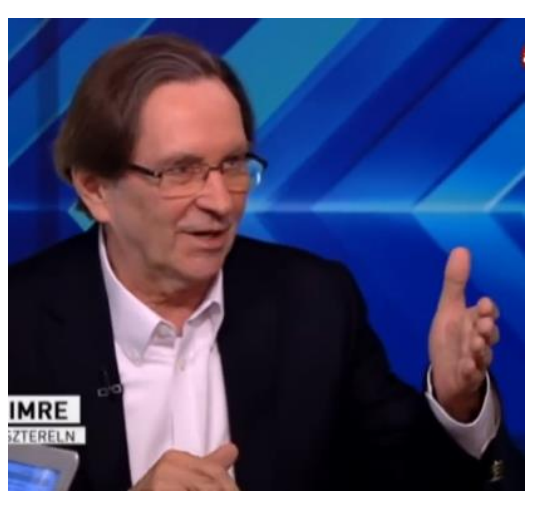

10. ábra

Palm lateral

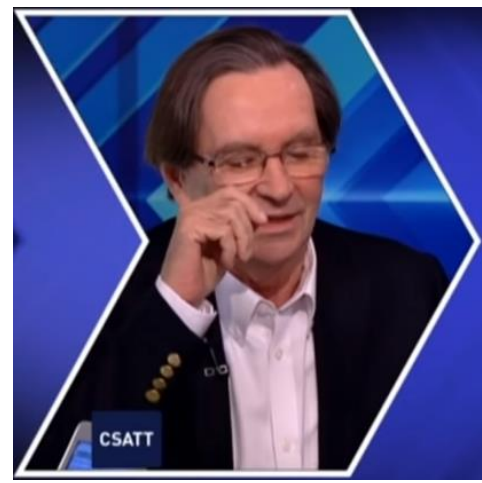

11. ábra

Palm vertical

C) A gesztus térbeli pozícióját tekintve McNeill (1992: 89) kilenc részre bontja a beszélő körüli teret, amelyek a következők:

\begin{tabular}{|c|c|}
\hline Position & A beszélő előtti térben a gesztus pozíciója \\
\hline Center & $\begin{array}{l}\text { A beszélő előtti tér, amely a két váll és a has közepe } \\
\text { közötti rész, tehát közvetlenül a törzs előtti tér }\end{array}$ \\
\hline Right & $\begin{array}{l}\text { A jobb válltól a has közepéig érő szakasz } \\
\text { a beszélőhöz viszonyított jobb oldalon }\end{array}$ \\
\hline Left & $\begin{array}{l}\text { A bal válltól a has közepéig érő szakasz } \\
\text { a beszélőhöz viszonyított bal oldalon }\end{array}$ \\
\hline Upper & A két váll és a fej fölötti tér \\
\hline Lower & A két csípö és a két térd közötti tér \\
\hline Upper right & A fej jobb oldalához és a jobb vállhoz viszonyított tér \\
\hline Upper left & A fej bal oldalához és a bal vállhoz viszonyított tér \\
\hline Lower right & $\begin{array}{l}\text { A törzs közepéhez viszonyított jobb oldal és } \\
\text { a jobb térd közötti tér }\end{array}$ \\
\hline Lower left & $\begin{array}{c}\text { A törzs közepéhez viszonyított bal oldal és } \\
\text { a bal térd közötti tér }\end{array}$ \\
\hline
\end{tabular}

3. táblázat

A gesztus térbeli, testhez viszonyított helyzete

D) A mozgás irányának leírásakor figyelembe vettük a laterális, a vertikális és sagitális tengelyeket, amelyek megkülönböztetésekor Bressem (2013) szempontjait módosítva a kar mozdulataira vonatkozóan a következő irányokat neveztük meg: 


\begin{tabular}{c|c} 
Direction of movement & Az elmozdulás iránya \\
\hline Right horizontal & Jobbra irányuló, vízszintes mozgás \\
\hline Left horizontal & Balra irányuló, vízszintes mozgás \\
\hline Up vertical & Felfelé irányuló, függőleges mozgás \\
\hline Down vertical & Lefelé irányuló, függőleges mozgás \\
\hline Far & $\begin{array}{c}\text { A testhez viszonyított, elsősorban centrális helyzetből } \\
\text { észrevehető, távolodó mozgás }\end{array}$ \\
\hline Close sagittal & $\begin{array}{c}\text { A testhez viszonyított, elsősorban a centrális } \\
\text { helyzethez, közeledő mozgás }\end{array}$ \\
\hline Close horizontal & $\begin{array}{c}\text { A két karra/kézre vonatkozó mozgás, amely során } \\
\text { a karok egymáshoz közelednek }\end{array}$ \\
\hline Out & $\begin{array}{c}\text { A két karra/kézre vonatkozó mozgás, amely során } \\
\text { a karok egymástól távolodnak }\end{array}$ \\
\hline Combination of axises & $\begin{array}{c}\text { Azon mozgások gyűjteménye, amelyek esetében } \\
\text { az előzőek nem érvényesülnek }\end{array}$ \\
\hline
\end{tabular}

4. táblázat

A kar mozgásának iránya a testhez viszonyítva

E) A mozgás minőségének leírásában Bressem (2013) jegyei közül eltekintettünk a mozgás nagyságának vizsgálatától, viszont a gesztuson belüli mozgásnak a temporális tulajdonságát és folyamatosságát beépítettük a kategória meghatározásába.

\begin{tabular}{c|c} 
Quality of movement & A mozgás minőségének jegyei \\
\hline+ Constant & $\begin{array}{c}\text { A beszélő kitartóan, ritmikusan mozgatja a kezét, } \\
\text { a tempó változatlan, konstans }\end{array}$ \\
\hline -Constant & $\begin{array}{c}\text { A beszélő nem szabályosan mozgatja a kezét, } \\
\text { a gesztus alatt a tempó váltakozik a gyorsabbról } \\
\text { a lassabbra, vagy fordítva }\end{array}$ \\
\hline Stable & A beszélő „kitartja” a gesztust, nem mozog \\
\hline One-way & $\begin{array}{c}\text { A beszélő a gesztussal elér egy pontot, } \\
\text { ahonnan már nem változtat a tempón }\end{array}$ \\
\hline
\end{tabular}

5. táblázat

A mozgás minősége

F) A mozgás típusa a csukló mozdulataira vonatkozik, Bressem (2013), illetve Bressem és társai (2013) az alapmozdulatok közé sorolta a csukló egyenes irányú mozgását, valamint a félkör ívben megvalósuló mozgást, a körkörös, a "cikcakk” alakú és a spirális mozdulatokat. A létrehozott annotációs keretben, követve Bressem (2013) kategóriáit, két csoportra osztjuk a csukló mozdulatait, a korlátozott, szabályozott és a szabályozatlan mozdulatok csoportjára. 


\begin{tabular}{c|c} 
Type of movement & A csukló mozdulatának tulajdonságai \\
\hline+ Restricted & A csukló egyenes vonalú mozgása \\
\hline -Restricted & A csukló nem egyenes vonalú mozgásai \\
\hline & $\begin{array}{c}\text { 6. táblázat } \\
\text { A csukló mozgása }\end{array}$
\end{tabular}

G) A vizsgálandó multimédiás korpusz esetében elengedhetetlen a fizikai kontextus részleges felvétele a kategóriák közé, mivel ebben a műsortípusban a beszélők egy asztal mögött foglalnak helyet, így a mozdulataik részben korlátozottak. Abban az esetben, ha egyik kar sem érinti az asztalt, hanem például a fej mellett valósul meg a mozgás, az adott szegmenst üresen hagyjuk. Az alábbi táblázat összefoglalja az asztalhoz és tárgyakhoz viszonyított mozgások lehetőségeit:

\begin{tabular}{|c|c|}
\hline Environment & Környezeti jellemzők \\
\hline One arm behind the table & $\begin{array}{l}\text { Az egyik kar az asztal mögött van, a másik nem ér } \\
\text { az asztalhoz és nem az asztal mögött van }\end{array}$ \\
\hline $\begin{array}{l}\text { Two arms behind the } \\
\text { table }\end{array}$ & $\begin{array}{l}\text { Mindkét kar az asztal mögött van, } \\
\text { egyik kéz sem látható }\end{array}$ \\
\hline One arm on the table & $\begin{array}{l}\text { Az egyik kar az asztalon van, a másik nincs } \\
\text { az asztalon és az asztal mögött sem }\end{array}$ \\
\hline Two arms on the table & Mindkét kar az asztalon pihen \\
\hline One elbow on the table & $\begin{array}{l}\text { Az egyik könyök az asztalon pihen, } \\
\text { a másik kar nem érinti az asztalt }\end{array}$ \\
\hline Two elbows on the table & Mindkét könyök az asztalon pihen \\
\hline $\begin{array}{l}\text { One arm on the table, one } \\
\text { elbow on the table }\end{array}$ & $\begin{array}{l}\text { Az egyik kar az asztalon hever, } \\
\text { a másik könyök az asztalon pihen }\end{array}$ \\
\hline $\begin{array}{l}\text { One arm on the table, one } \\
\text { arm behind the table }\end{array}$ & $\begin{array}{l}\text { Az egyik kar az asztalon hever, } \\
\text { a másik az asztal mögött helyezkedik el }\end{array}$ \\
\hline $\begin{array}{l}\text { One hand touches the } \\
\text { pen/the paper/the glasses }\end{array}$ & $\begin{array}{l}\text { Az egyik kéz valamit tart, ami lehet egy toll, } \\
\text { egy papír vagy a szemüveg, de a kar térbeli pozíciója } \\
\text { megadható a további kategóriák által }\end{array}$ \\
\hline
\end{tabular}

H) Az annotációs sémában megneveztünk egy újabb kategóriát, amely a kezek számára vonatkozik. Ez a kategória részben arra szolgál, hogy felfedjük a szimmetrikus gesztusokat, illetve megállapítsuk, hogy egy gesztus létrehozásakor mekkora mozgást hajt végre a beszélő, például a gesztus a beszélőhöz képest a bal oldalon (Positon) zajlik, viszont a beszélő jobb keze mozog. Továbbá leírhatóvá válnak azon esetek is, melyekben felfedjük a kar és a kéz helyzetét a testhez viszonyítva az Environment kategória segítségével, viszont a további szempontok irrelevánssá válnak abban az esetben, ha a beszélő gesztikulációja passzív (None). 


\begin{tabular}{c|c} 
Number of hands & Gesztust megvalósító kéz/kezek \\
\hline Right & A beszélő a jobb kezével hajtja végre a gesztust \\
\hline Left & A beszélő a bal kezével hajtja végre a gesztust \\
\hline Both & $\begin{array}{r}\text { Mindkét kézzel gesztikulál, } \\
\text { főként szimmetrikus gesztus fedezhető fel }\end{array}$ \\
\hline None & Mindkét keze passzív, nem valósít meg gesztust \\
\hline
\end{tabular}

8. táblázat

A gesztust megvalósító kézfejek meghatározása

\subsection{A beszéd annotálása}

A beszéd megnyilatkozásokra való tagolása elsősorban Németh T. (1994) alapján valósult meg, ugyanakkor a vitaműsor müfajából fakadóan néhány megnyilatkozás monologikus jelleggel bírt, emiatt egyes esetekben nélkülözhetetlen volt a megnyilatkozások további szegmensekre való bontása. A leírás során Jefferson (2004) konverzációelemzési átírási konvencióit követjük. A társalgáselemzés által alkalmazott leírás segítségével a beszélőváltásokhoz, a javításokhoz, a beszélő kijelöléséhez és a nevetéshez társuló gesztusok feltárása lehetővé válik.

További annotációs szintnek bevezetjük a gesztus funkcióját/formáját (ld. 3. pont), amely a beszédhez viszonyított gesztusfunkciót jelöli. A funkciót vizsgálva elkülönítünk négy fő csoportot: az ábrázolás (representational) és az ütemezés (beat) funkciókat, továbbá az azonosítatlan gesztusokat és az állapotot azonosítjuk, az ábrázoló funkció esetén alkategóriának bevezetjük az ikonikus, a deiktikus gesztusokat és az emblémákat, az ütemezés pedig a ritmikus gesztusokat jelöli.

A létrehozott keret előnye, hogy figyelembe veszi a környezeti tényezőket, így vizsgálhatóvá válik az, hogy a beszélők a kar és a kéz mozdulatai során milyen mértékben használják ki az adott teret. A kutatással különböző gesztusok azonosítása valósulhat meg, tehát rendszerezhetővé válhatnak. Továbbá a keret alapján leírhatóvá válnak a szimmetrikus kar- és kézmozdulatok, amely további vizsgálódásra ad lehetőséget.

A dolgozat következő felében egy esetelemzés során bemutatjuk az annotációs keret alkalmazhatóságát a vizsgált korpuszunk alapján, amely politikai vitaműsorokat tartalmaz. A kiinduló hipotézisünk korábbi megfigyeléseinken nyugszik, miszerint a vitaműsorok résztvevői heves érzelmi állapotban, gyakran a nyelvileg agresszív megnyilatkozások által kísért szituációkban ütemező, ritmikus gesztusokat alkalmaznak.

\section{Esetelemzés}

\subsection{A felhasznált videók tulajdonságai}

A multimédiás korpuszunkból 23 percnyi anyagot elemeztünk, mivel a létrehozott annotációs keret kipróbálásához elegendő ekkora korpusz. Az elemzett videóanyag három eltérő vitaműsorból származik, különböző résztvevőkkel. 
A korpusz hiányosságának minősül a kameraállások meghatározottsága, így a teljes testbeszédet nincs lehetőségünk vizsgálni, továbbá csupán a produkciós oldalt látjuk, mivel a felvételeken elsősorban az aktuális beszélő látható, így nem áll módunkban a hallgató testbeszédén (főként gesztusain) mutatkozó reakciókat feltárni. A kutatásunkban a verbális és a nem verbális kommunikációt együttesen vizsgáljuk, elsősorban a beszéd és a gesztusok közötti szemantikai és pragmatikai kapcsolatra fókuszálunk, amely elősegítheti a kultúraspecifikus gesztusok rendszerezését, illetve a nem verbális kódhasználat és a beszéd tartalma közötti kapcsolat feltárását.

A videórészletek közötti választást meghatározza az, hogy a korpusz teljes videóanyagának ismeretében olyan videórészleteket emeljünk ki, melyekben a résztvevők legalább egyikét meglepetésként éri a vitapartnere nyelvi viselkedése, illetve a résztvevő nyelvi viselkedése nyelvi agressziónak minősül. A nyelvi agressziót Szabó (2020: 33-34) definíciója alapján kezeljük, amely a következő: „a nyelvi agresszió olyan nyelvi viselkedés és stratégiák gyűjteménye, illetve a nyelvi és nyelvhasználati eszközök olyan használata, amelyek segítségével az adott kontextust és az adott szociális távolságot felmérve a beszélői viselkedés mögött ellenségeskedő, ártó szándék feltételezhető, illetve mind a befogadó, mind a szituációs, vagy az adott társadalmi-kulturális kontextus szerint nyelvileg agresszívnek interpretálható”. Szabó (2020) a politikai vitaműsorokat vizsgálva három stratégiát különít el a nyelvi agresszióra vonatkozóan: (1) a negatív attitűd kifejezése, (2) a partnertől/partner csoportjától való eltávolodás, és (3) az egyet nem értés maximalizálása. A három videórészlet ennek függvényében a három különböző stratégia prototipikus példányainak tekinthető.

Az első videóban ${ }^{3}$ a negatív attitűd kifejezésének stratégiája érvényesül, mivel a vitapartnerek egymás iránti ellenszenvüket fejezik ki. A videórészlet hossza 5 perc 29 másodperc, a beszélők közt helyet foglal Bencsik András, Farkasházy Tivadar, Kerényi Imre és a moderátor, Rónai Egon. Mindhárom részlet esetében a beszélgetés részletes ismertetése szükséges ahhoz, hogy a nyelvi agresszió stratégiájának meghatározása nyilvánvaló legyen. Ebben az adásban Bencsik András korábbi újságcikke kerül szóba, amelyben a Heti Hetes című müsor ártékony voltáról ír, illetve arról, hogy a műsor résztvevőit meg kellene büntetni. Farkasházy a Heti Hetes egyik állandó szereplőjeként felolvassa Bencsik újságcikkét, majd megkérdezi, hogy ki és mikor írta azt. E kérdés arculatfenyegető Bencsikkel szemben. Bencsik nem emlékszik erre az újságcikkre, ezért meglepődik, majd felháborodik a kérdésen. Farkasházy és Bencsik elmondása alapján ez az első, egyben az utolsó alkalom, amikor egy asztalnál foglalnak helyet.

${ }^{3} \mathrm{~A}$ videó elérhetősége: https://youtu.be/ls7fhjFE60g (utolsó hozzáférés: 2020. 02. 27.) 


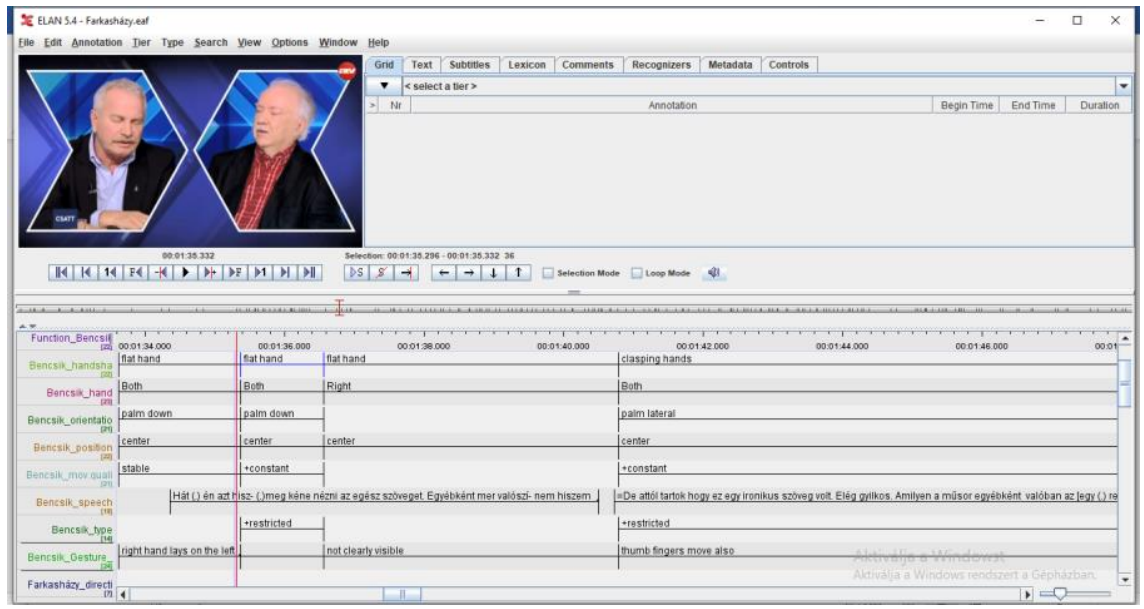

12. ábra

ELAN-ablak az első videó annotációs felületéről

\begin{tabular}{|l|l|l|l|}
\hline Farkasházy_speech & $=$ Akkor ennyit enröl.] & Jó, hagyjuk h elmondtam amit akartam. & \\
\hline TC & $00: 04: 37.377-00: 04: 38.452$ & $00: 04: 41.528-00: 04: 44.018$ & \\
\hline Rónai_speech & & Jó. \\
\hline TC & & $00: 04: 44.226-00: 04: 44.566$ \\
\hline
\end{tabular}

\begin{tabular}{|l|l|}
\hline Rónai_speech & $\begin{array}{l}\text { Szerintem az fontos hogy ha már ez igy alakult hogy egy asztalnál ültök (.) akkor erröl tudjatok beszélni. Szerintem az adás } \\
\text { után is lesz még mit, de akkor most valóban lépjünk [tovább]. }\end{array}$ \\
\hline TC & 00:04:45.452 - 00:04:54.433 \\
\hline
\end{tabular}

\begin{tabular}{|l|l|}
\hline Bencsik_speech & $\begin{array}{l}\text { [ Egy mondatot] (.)Csak [hadd] engedjem meg tehát (.) most ültem utoljára Farkasházy Tivadarral e- egy asztalnál ho ez egy } \\
\text { méltatlan helyzet volt, és kikérem magamnak hogy }=\end{array}$ \\
\hline TC & $00: 04: 54.622-00: 05: 03.261$ \\
\hline
\end{tabular}

\begin{tabular}{|l|l|l|}
\hline Bencsik_speech & & $=$ hogy $($.$) lehet dédelgetni sebeket ($.$) de a ($.$) akkor hadd mondjak annyit hogy ()=$. \\
\hline TC & & $00: 05: 03.320-00: 05: 10.377$ \\
\hline Rónai_speech & [Hogy]ne. & \\
\hline TC & $00: 04: 54.754-00: 04: 55.660$ & \\
\cline { 1 - 1 } & &
\end{tabular}

\begin{tabular}{|l|l|}
\hline Bencsik_speech & $\begin{array}{l}\text { =az a músor olyan kártékony volt, olyan ártalmas volt, olyan sok (.)öōöö rosszat okozott ennek az országnak hogy (.) } \\
\text { valószinüleg jogos indulatomban irtam le amit írtam. És egyáltalán nem érzem úgy, hogy ezért magamat szégyellni kellene, }\end{array}$ \\
\hline TC & 00:05:10.830 - 00:05:26.181 \\
\hline
\end{tabular}

\begin{tabular}{|l|l|}
\hline Bencsik_speech & $\dot{E} s$ alkor mehetünk tovább. \\
\hline TC & $00: 05: 26.226-00: 05: 27.471$ \\
\hline
\end{tabular}

\section{3. ábra \\ Társalgásrészlet az 1 . videóból ${ }^{4}$}

${ }^{4}$ Az átírási konvenciót a Függelék-ben található. Az ELAN sajátosságai miatt az átfedésben levő részek nem kerülhettek közvetlen egymás alá, ahogyan az a konverzációelemzésben a szokásos átírási mód. 
Farkasházy: =Akkor ennyit erről.] Jó, hagyjuk .h elmondtam, amit akartam.

Rónai: Jó. Szerintem az fontos hogy ha már ez így alakult hogy egy asztalnál ültök (.) akkor erről tudjatok beszélni. Szerintem az adás után is lesz még mit, de akkor most valóban lépjünk (0.2) [tovább.]

Bencsik: [Egy mondatot], csak [hadd]=

Rónai:

Bencsik: [Hogy]ne.

=engedjem meg tehát $($.$) most ültem$ utoljára Farkasházy Tivadarral e- egy asztalnál h. ez egy méltatlan helyzet volt, és kikérem magamnak, hogy hogy (.) lehet dédelgetni sebeket (.) de a (.) akkor hadd mondjak annyit hogy (.) az a müsor olyan kártékony volt, olyan ártalmas volt, olyan sok (.) öö öö rosszat okozott ennek az országnak hogy (.) valószínűleg jogos indulatomban írtam le amit írtam. És egyáltalán nem érzem úgy, hogy ezért magamat szégyellni kellene, és akkor mehetünk tovább.

A második videóban ${ }^{5}$ a csoporttól való eltávolodás stratégiája érvényesül. A vitamüsorban Gajdics Ottó, G. Fodor Gábor, Tóth Csaba, Závecz Tibor és a moderátor, Dobos M. Marianne vesznek részt, a kiválasztott részlet 11 perc. A vita témája a bevándorlás és a menekültválság. Gajdics és G. Fodor azonos állásponton vannak, mindketten ellenzik a bevándorlást, és az Orbán-kormány támogatói. Míg Tóth és Závecz nem ellenzik a bevándorlást és nem támogatják az Orbán-kormányt. Tóth e videórészletben Gajdics és G. Fodor megnyilatkozásait a propagandához hasonlítja, tehát a résztvevők az egymás eszméitől és csoportjától való eltávolodásra törekednek.

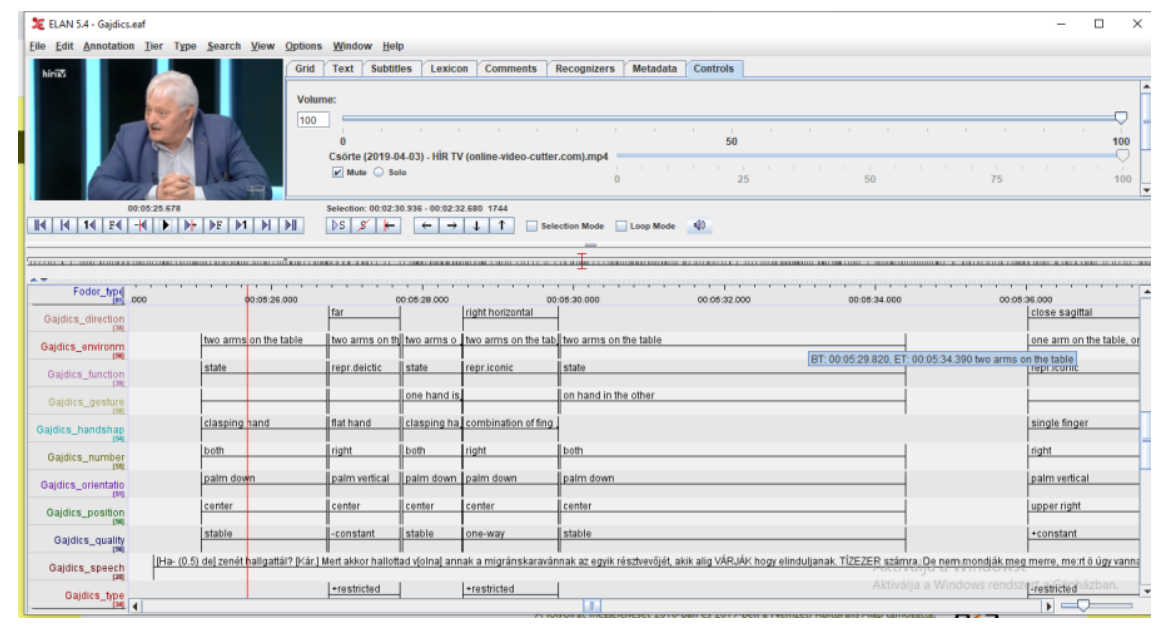

14. ábra

ELAN-részlet a 2. videóból

${ }^{5}$ https://hirtv.hu/csorte/csorte-ertekalapu-meg-vagy-valsagban-van-europa-2479260 A választott részlet a 24:44-nél indul, 35:45-nál ér véget. (utolsó hozzáférés: 2020. 02. 27.) 
a jelentos resze, amit a kormany oldala ezzel kapcsolatbban mond, az catolva van.] 00:02:23.723 - 00:02:32.872

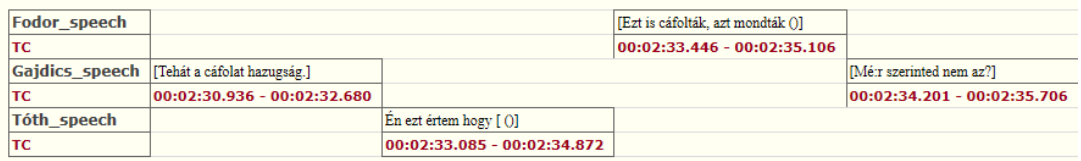

\begin{tabular}{|l|l|}
\hline Dobos_speech & [Jobb a nyugalom] \\
\hline TC & $00: 02: 34.276-00: 02: 35.255$ \\
\hline
\end{tabular}

\begin{tabular}{|l|l|}
\hline Tóth_Speech & $\begin{array}{l}{[\text { Még e- még egy mondatot sem tudtam] ez ügyben végigmo[ndani]. Ami jól mutatja azt, ami jól mutatja azt Ottó, hogy mennyire }} \\
\text { torzit az ezzel kapcsolatos kommuni[kációtok.] }\end{array}$ \\
\hline TC & 00:02:35.148 - 00:02:43.247 \\
\hline
\end{tabular}

Dobos_speech [ $\gg$ Hadd mondja végig a Csaba $<]$

\begin{tabular}{|l|l|l|}
\hline TC & $00: 02: 36.457-00: 02: 37.557$ & \\
\hline Fodor_speech & & {$[$ Hảt ((nevet))] } \\
\hline TC & & $00: 02: 37.659-00: 02: 39.042$ \\
\hline
\end{tabular}

\begin{tabular}{|l|l|l|l|}
\hline Dobos_speech & [Vagy csak anny]ira foglalkoztat minden[kit, hogy mindenki szeretné elmondani a véleményét.] Hadd mond[ja végig a Csaba.] \\
\hline
\end{tabular} \begin{tabular}{l|l} 
TC & $00: 02: 42.868-00: 02: 48.549$
\end{tabular}

\begin{tabular}{|l|l|l|l}
\hline Fodor_speech [Mutassunk már egy képet arról az anonimkartyáról] & [hogy az van-e vagy nincs?]
\end{tabular}

\begin{tabular}{|l|l|l|}
\hline TC & $00: 02: 43.978-00: 02: 46.808$ & $00: 02: 47.531-00: 02: 48.872$ \\
\hline
\end{tabular}

15. ábra

Társalgásrészlet a 2. videóból

Tóth: =a jelentős része, amit a kormány oldala ezzel kapcsolat[ban mond, az cáfolva van.]

Gajdics:

cáfolat hazugság.]

Tóth: Én ezt értem hogy [( $)]$

Fodor:

Gajdics:

[Ezt is cáfolták, ] [azt mondták, ( )

[Mé:r szerinted [nem az? ]]

Dobos:

Tóth: [Még e- még egy mondatot sem tudtam]=

[Jobb a nyugalom.]

Dobos: [>Hadd mondja végig a Csaba < ]

Tóth:

Fodor:

=ez ügyben végig [mondani.]

[Hát

((nevet))]

[Tehát a

Tóth: $\quad$ Ami jól mutatja azt, ami jól mutatja azt Ottó, hogy mennyire torzít az ezzel kapcsolatos kommuni[kációtok.]

Dobos:

[Vagy csak annyi]ra foglalkoztat minden[kit, hogy mindenki szeretné elmondani véleményét.]=

Fodor: [Mutassunk már egy képet arról az anonimkártyáról]=

Dobos:

mond[ja végig a Csaba.]

$=$ Hadd

Fodor: $\quad=$ [hogy az van-e vagy nincs?] 
A harmadik videórészletben ${ }^{6}$ az egyet nem értés maximalizálásának stratégiája érvényesül. A vitaműsorban Boros Tamás, Kovács Zoltán, Stefka István, Zárug Péter Farkas és a moderátor, Rónai Egon jelentek meg, a vizsgált részlet 7 perc 20 másodperc. A vita témája a kormány családpolitikája, illetve az, hogy a kormány mit tekint családnak. Ugyanakkor a vitában összetűzésbe kerül a résztvevők egyéni családfelfogása is, mivel Stefka és Zárug a férfi-női kapcsolatot részesítik előnyben, valamint a gyermekvállalást tekintik életcélnak. Velük szemben Boros és Kovács kijelentik, hogy a család fogalma nem merül ki a férfi-női kapcsolatban, illetve házasságban, ezenkívül hangsúlyozzák, hogy nem minden ember számára fontos a gyermekvállalás.

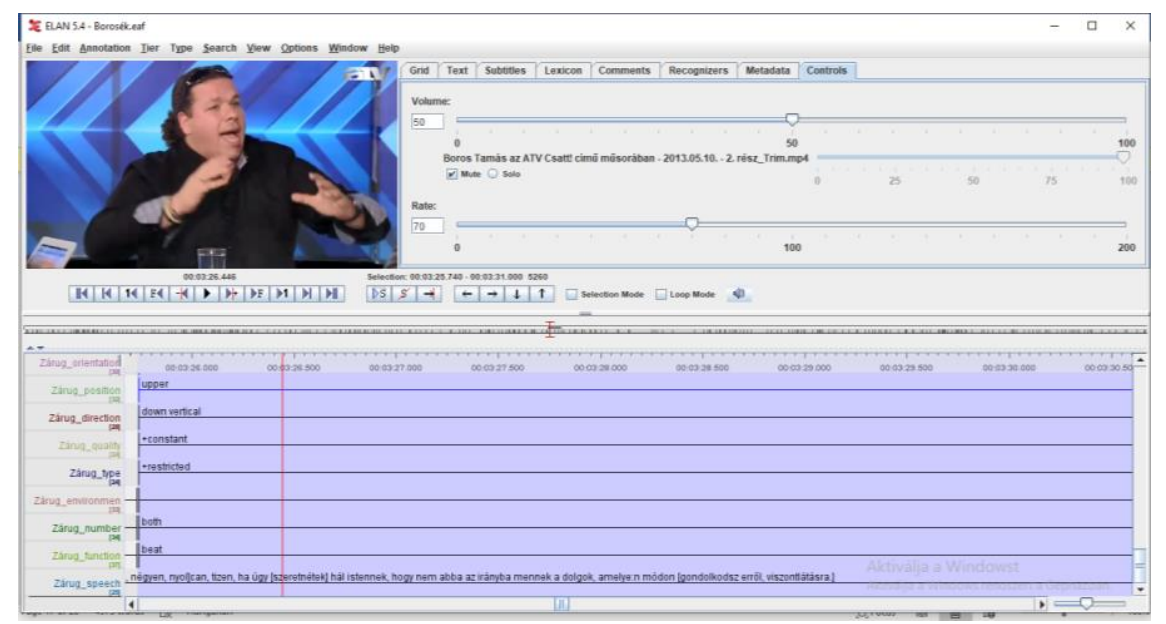

16. ábra

ELAN-ablak a 3. videóból

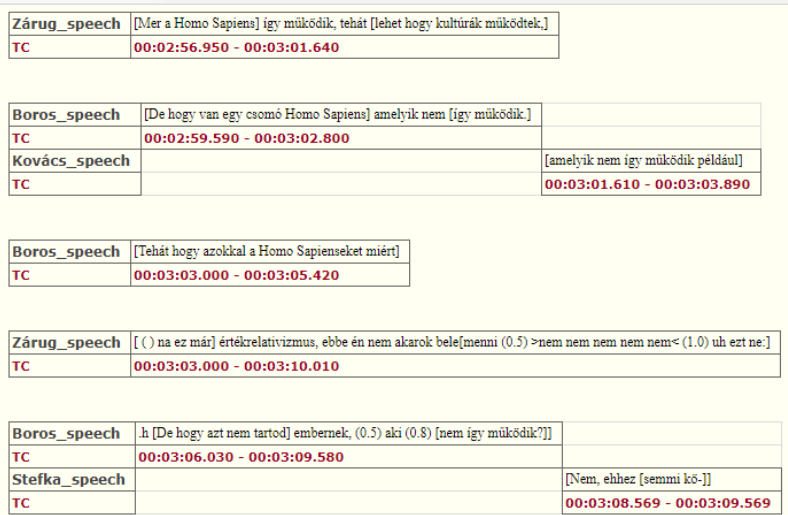

${ }^{6} \mathrm{https}: / /$ www.youtube.com/watch?v=Ja8S7lvli-k\&t=850s 


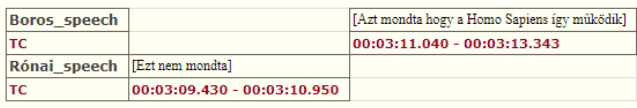

\begin{tabular}{|l|l|}
\hline Stefka_speech & [Figyelj csak (0.5) ne:m, ne:m, hát mos meg mások 0] \\
\hline TC & $00: 03: 11.400-00: 03: 14.150$
\end{tabular}

17. ábra

Társalgásrészlet a 3. videóból

Zárug: [Mer a Homo Sapiens] így müködik, tehát [lehet hogy kultúrák müködtek,]

Boros:

Homo Sapiens] amelyik nem [így müködik. ]

[De hogy van egy csomó

Kovács:

Boros: [Tehát hogy azokkal a Homo Sapienseket miért]

Zárug: [( ) na ez már] értékrelativizmus, ebbe én nem akarok bele[menni (0.5) $>$ nem nem nem nem nem< (1.0) uh ezt (0.5) ne:]

Boros:

nem tartod embernek, (0.5) aki [(0.8) nem így müködik?]]

.h [De hogy azt

Stefka:

[Nem, ehhez [semmi kö-]]

Rónai:

Boros:

[Azt mondta hogy a Homo Sapiens így működik ]

[Ezt nem mondta]

Stefka: [Figyelj csak (0.5) ne:m, ne:m, hát mos meg mások ()]

\subsection{A beszéd és a gesztusfunkciók kapcsolata}

Ebben a részben bemutatjuk a különböző gesztusfunkciók előfordulásának számát. Az első videóban 105, a második videóban 335, a harmadik videóban 208 gesztusegységet különítettünk el. A kameraállásoknak köszönhetően nem minden esetben volt látható a beszélő keze, ugyanakkor a testtartás, a vállmozdulatok és a tekintet is árulkodik arról, hogy a beszélő gesztikulál-e vagy sem, viszont ezen esetekhez nem rendeltünk gesztusfunkciót. A gesztusfunkciók előfordulásának számát az ELAN keresőfelülete alapján összegeztük.

A meghatározott gesztusfunkciók száma a következő:

\begin{tabular}{c|c} 
Gesztusfunkció az 1. videóban & Előfordulások száma \\
\hline Reprezentális-ikonikus & 51 \\
\hline Reprezentális-deiktikus & 10 \\
\hline Reprezentális-embléma & 13 \\
\hline Ütemezést tanúsító gesztusok (beat) & 40 \\
\hline Állapot & $\begin{array}{c}\text { (abban az esetben, ha beszéd } \\
\text { közben mozdulatlan) }\end{array}$ \\
\hline Azonosítatlan (undetermined) & 11
\end{tabular}

9. táblázat

A gesztusfunkciók megoszlása az 1. videóban 


\begin{tabular}{c|c} 
Gesztusfunkciók a 2. videóban & Elöfordulások száma \\
\hline Reprezentális-ikonikus & 69 \\
\hline Reprezentális-deiktikus & 38 \\
\hline Reprezentális-embléma & 6 \\
\hline Ütemezést tanúsító gesztusok (beat) & 38 \\
\hline Állapot & $\begin{array}{c}\text { (abban az esetben, ha beszéd } \\
\text { közben mozdulatlan) }\end{array}$ \\
\hline Azonosítatlan (undetermined) & 10
\end{tabular}

10. táblázat

A gesztusfunkciók megoszlása 2. videóban

\begin{tabular}{c|c} 
Gesztusfunkciók a 3. videóban & Előfordulások száma \\
\hline Reprezentális-ikonikus & 18 \\
\hline Reprezentális-deiktikus & 16 \\
\hline Reprezentális-embléma & 0 \\
\hline Ütemezést tanúsító gesztusok (beat) & 17 \\
\hline Állapot & 28 (abban az esetben, ha beszéd \\
& közben mozdulatlan) \\
\hline Azonosítatlan (undetermined) & 13
\end{tabular}

11. táblázat

A gesztusfunkciók megoszlása a 3. videóban

A vizsgálattal teszteltük az annotációs séma alkalmasságát, ugyanakkor a korpusz típusából fakadóan nem állt módunkban az összes gesztusegység és azok tulajdonságainak meghatározása. Az esetelemzés kiinduló hipotézisével ellentétes eredményre jutottunk, mivel az ütemező gesztusok kisebb mértékben fordultak elő a vizsgált anyagban. Megállapítottuk, hogy a nyelvileg agresszív megnyilatkozások során az ütemező gesztusok mellett ikonikus gesztusokat alkalmaznak a beszélők, illetve egyes esetekben nem kíséri gesztus (state) a nyelvi agressziót. Ebből arra következtethetünk, hogy a nyelvileg agresszív megnyilatkozások megfontoltak és kontrolláltak a politikai vitaműsorokban, így a heves érzelmi állapotok kevésbé befolyásolják a gesztikulációt.

\section{7. Összegzés}

Dolgozatunkban kitértünk a nem verbális kommunikáció funkcióira, elsősorban a gesztusokra fókuszálva. Áttekintettük a gesztusok annotálási szempontjait, majd leírtunk egy olyan annotációs sémát, amely a beszélgetőműsorok multimodális elemzését elősegíti.

A felvázolt kategóriák elsősorban a beszélgetőműsorokban megjelenő gesztusok annotálására szolgálnak, viszont egyes kategóriák tovább bővíthetőek a környezeti 
tényezőknek megfelelően. Ezzel az annotációs sémával lehetővé válik a gesztus és a beszéd együttes elemzése, valamint különböző gesztusegységeket határozhatunk meg, amelyekhez funkciót rendelve megállapíthatjuk, hogy mely gesztusok szolgálnak a diskurzus koherenciájának megteremtésére, illetve mely gesztusok segítségével valósul meg az érzelmek és mentális állapotok kifejezése.

Az ismertetett annotációs séma segítségével jelenleg a politikai vitaműsorokban megjelenő verbális agressziót és az azt kísérő gesztusokat vizsgáljuk. A vizsgálat eredményeivel feltehetőleg létrehozhatunk egy olyan modellt, amellyel a verbális agressziót detektálhatjuk nem verbális szinten.

A kutatásunk következő szakaszában egy kibővített korpuszban alkalmazzuk a létrehozott annotációs keretet, a hétköznapi témájú diskurzusokban megjelenő gesztikulációt összevetjük egy nagyobb, politikai vitamüsorokat tartalmazó korpusszal. Ezenkívül a multimodális magyar nyelvű korpuszok segítségével feltárhatóvá válhatnak magyar kultúraspecifikus gesztusok (emblémák), melyekkel az intra- és interkulturális kommunikációkutatásokhoz is hozzájárulhatunk.

\section{Köszönetnyilvánítás}

A tanulmány elkészülését az Új Nemzeti Kiválósági Program UNKP-19-3-SZTE265 kódú ösztöndíj támogatta.

\section{Hivatkozások}

Abuczki Ágnes 2011. A multimodális interakció szekvenciális elemzése. In Németh T. Enikő (szerk.) Ember-gép kapcsolat. A multimodális ember-gép kommunikáció modellezésének alapjai. (Segédkönyvek a nyelvészet tanulmányozásához 133) Budapest: Tinta Könyvkiadó. 119-144.

Alibali, Martha W. - Dana C. Heath - Heather J. Myers 2001. Effects of visibility between speaker and listener on gesture production: Some gestures are meant to be seen. Journal of Memory and Language 44/2:169-188. doi:10.1006/jmla.2000.2752.

Blache, Philippe - Roxane Bertrand - Emmanuel Bruno - Brigitte Bigi - Robert Espesser et al. 2010. Multimodal annotation of conversational data. Proceedings of the Fourth Linguistic Annotation Workshop. Uppsala: Association for Computational Linguistics. 186-191.

Bressem, Jana 2013. A linguistic perspective on the notation of form features in gestures. In Cornelia Müller - Alan Cienki - Ellen Fricke - Silva Ladewig David McNeill - Sedinha Tessendorf (szerk.) Body - Language Communication. An International Handbook on Multimodality in Human Interaction. Vol. 1. Berlin, Boston: De Gruyter. 1079-1098. doi:10.1515/9783110261318.1079.

Bressem, Jana - Silva H. Ladewig - Cornelia Müller 2013. Linguistic Annotation System for Gestures. In Cornelia Müller - Alan Cienki - Ellen Fricke - Silva Ladewig - David McNeill - Sedinha Tessendorf (szerk.) Body - Language Communication. An International Handbook on Multimodality in Human Interaction. Vol. 1. Berlin, Boston: de Gruyter. 1098-1124. doi:10.1515/9783110261318.1098. 
Brook, Rebecca - Maroš Servátka 2016. The anticipatory effect of nonverbal communication. Economics Letters 144:45-48. doi:10.1016/j.econlet.2016.04.033.

Ekman, Paul 1971. Universals and cultural differences in facial expressions of emotion. In James K. Cole (szerk.) Nebraska Symposium on Motivation. Vol. 19. Lincoln: University of Nebraska Press. 207-284.

Ekman, Paul - Wallace V. Friesen 1981. The repertoire of nonverbal behavior: Categories, origins, usage, and coding. In Adam Kendon - Thomas A. Sebeok - Jean Umiker-Sebeok (szerk.) Nonverbal Communication, Interaction, and Gesture. (Approach to Semiotics 41) Berlin, New York: Mouton Publishers. 57-106. doi:10.1515/9783110880021.57.

ELAN 2019. Version 5.8. Nijmegen: Max Planck Institute. https://archive.mpi.nl/tla/elan.

Esposito, Anna - Alessandro Vinciarelli - Klára Vicsi - Catherine Pelachaud Anton Nijholt (szerk.) 2011. Analysis of Verbal and Nonverbal Communication and Enactment. The Processing Issues: COST 2102 International Conference, Budapest, Hungary, September 7-10, 2010. (Lecture Notes in Computer Science 6800) Berlin, Heidelberg: Springer.

Fasola, Alexia - F. -Xavier Alario - Marion Tellier - Bernard Giusiano - Carlo Alberto Tassinari - Fabrice Bartolomei - Agnès Trébuchon 2020. A description of verbal and gestural communication during postictal aphasia. Epilepsy \& Behavior 102:106646. doi:10.1016/j.yebeh.2019.106646.

Hall, Edward T. 1963. A system for the notation of proxemic behavior. American Anthropologist 65/5:1003-1026. doi:10.1525/aa.1963.65.5.02a00020.

Hogg, Michael A. - Graham M. Vaughan 2018. Language and Communication. In Michael A. Hogg - Graham M. Vaughan Social psychology. 8. kiadás. Pearson Education. 596-636.

Hunyadi László 2011a. A multimodális ember-gép kommunikáció modellezésének alapjai. In Németh T. Enikő (szerk.) Ember-gép kapcsolat. A multimodális ember-gép kommunikáció modellezésének alapjai. (Segédkönyvek a nyelvészet tanulmányozásához 133) Budapest: Tinta Könyvkiadó. 7-14. Hunyadi László 2011b. A multimodális ember-gép kommunikáció technológiái. Elméleti modellezés és alkalmazás a beszédfeldolgozásban. In Németh T. Enikő (szerk.) Ember-gép kapcsolat. A multimodális ember-gép kommunikáció modellezésének alapjai. (Segédkönyvek a nyelvészet tanulmányozásához 133) Budapest: Tinta Könyvkiadó. 15-42.

Hunyadi László - Földesi András - Szekrényes István - Kiss Hermina - Abuczki Ágnes - Bódog Alexa 2012. Az ember-gép kommunikáció elméletitechnológiai modellje és nyelvtechnológiai vonatkozásai. In Prószéky Gábor Váradi Tamás (szerk.) Általános Nyelvészeti Tanulmányok XXIV. Nyelvtechnológiai kutatások. Budapest: Akadémiai Kiadó. 265-309.

Ilie, Cornelia 2001. Semi-institutional discourse: The case of talk shows. Journal of Pragmatics 33/2:209-254. doi:10.1016/S0378-2166(99)00133-2.

Jefferson, Gail 2004. Glossary of transcript symbols with an introduction. In Gene H. Lerner (szerk.) Conversation Analysis: Studies from the First Generation. (Pragmatics \& Beyond New Series 125) Amsterdam: John Benjamins Publishing Company. 13-31. doi:10.1075/pbns.125.02jef. 
Kendon, Adam 1980. Gesticulation and speech: Two aspects of the process of utterance. In Mary Ritchie Key (szerk.) Nonverbal Communication and Language. Hague: Mouton. 207-277.

Kendon, Adam 2000. Language and gesture: unity or duality? In David McNeill (szerk.) Language and Gesture. (Language Culture and Cognition 2) Cambridge: Cambridge University Press. 47-63. doi:10.1017/CBO9780511620850.004.

Kendon, Adam 2004. Gesture. Visible Action as Utterance. Cambridge: Cambridge University Press.

Kendon, Adam - Thomas A. Sebeok - Jean Umiker-Sebeok (szerk.) 1981. Nonverbal Communication, Interaction, and Gesture. (Approaches to Semiotics 41) Hague: De Gruyter Mouton.

Kirk, Lorraine - Michael Burton 1981. Physical versus semantic classification of nonverbal forms: A cross-cultural experiment. In Adam Kendon - Thomas A. Sebeok - Jean Umiker-Sebeok (szerk.) Nonverbal Communication, Interaction, and Gesture. (Approaches to Semiotics 41) Hague: De Gruyter Mouton. 459-482. doi:10.1515/9783110880021.459.

Kita, Sotaro - Asli Özyürek 2003. What does cross-linguistic variation in semantic coordination of speech and gesture reveal? Evidence for an interface representation of spatial thinking and speaking. Journal of Memory and Language 48/1:16-32. doi:10.1016/S0749-596X(02)00505-3.

Kong, Anthony Pak-Hin - Sam-Po Law - Connie Ching-Yin Kwan - Christy Lai Vivian Lam 2015. A coding system with independent annotations of gesture forms and functions during verbal communication: Development of a Database of Speech and GEsture (DoSaGE). Journal of Nonverbal Behavior 39/1:93-111. doi:10.1007/s10919-014-0200-6.

Kostić, Aleksandra - Derek Chadee (szerk.) 2015. The Social Psychology of Nonverbal Communication. London: Palgrave Macmillan.

Ladewig, Silva H. - Jana Bressem 2013. A linguistic perspective on the notation of gesture phases. In Cornelia Müller - Alan Cienki - Ellen Fricke - Silva Ladewig - David McNeill - Sedinha Tessendorf (szerk.) Body - Language Communication. An International Handbook on Multimodality in Human Interaction. Vol. 1. Berlin, Boston: de Gruyter. 1060-1079. doi:10.1515/9783110261318.1060.

Mather, Susan M. 2005. Ethnographic research on the use of visually based regulators for teachers and interpreters. In Melanie Metzger - Earl Fleetwood (szerk.) Attitudes, Innuendo, and Regulators: Challenges of Interpretation. Washington, DC: Gallaudet University Press. 131-161.

Matsumoto, David - Mark Frank - Hyi Hwang 2013. Nonverbal Communication: Science and Applications. London: Sage Publications.

McNeill, David 1992. Hand and Mind. What Gestures Reveal about Thought. Chicago: University of Chicago Press.

McNeill, David 2005. Gesture and Thought. Chicago: University of Chicago Press. 
McNeill, David 2013. Gesture as a window onto mind and brain, and the relationship to linguistic relativity and ontogenesis. In Cornelia Müller - Alan Cienki - Ellen Fricke - Silva Ladewig - David McNeill - Sedinha Tessendorf (szerk.) Body - Language - Communication. An International Handbook on Multimodality in Human Interaction. Vol. 1. Berlin, Boston: de Gruyter. 28-54. doi:10.1515/9783110261318.28.

Müller, Cornelia - Silva H. Ladewig - Jana Bressem 2013. Gestures and speech from a linguistic perspective: A new field and its history. In Cornelia Müller Alan Cienki - Ellen Fricke - Silva Ladewig - David McNeill - Sedinha Tessendorf (szerk.) Body - Language - Communication. An International Handbook on Multimodality in Human Interaction. Vol. 1. Berlin, Boston: de Gruyter. 55-81. doi:10.1515/9783110261318.55.

Németh T. Enikő 1989. Az emberi kommunikáció kutatásának néhány alapkérdése. Néprajz és Nyelvtudomány 33:43-56.

Németh T. Enikő 1994. Megnyilatkozás: típus-példány. Néprajz és Nyelvtudomány 35:69-101.

Patterson, Miles L. 1983. Nonverbal Behavior. A Functional Perspective. New York: Springer.

Patterson, Miles L. 1994. Interaction behavior and person perception: An integrative approach. Small Group Research 25/2:172-188. doi:10.1177/1046496494252002.

Ramseyer, Fabian - Wolfgang Tschacher 2010. Nonverbal synchrony or random coincidence? How to tell the difference. In Anna Esposito - Nick Campbell Carl Vogel - Amir Hussain - Anton Nijholt (szerk.) Development of Multimodal Interfaces: Active Listening and Synchrony: Second COST 2102 International Training School, Dublin, Ireland, March 23-27, 2009. (Lecture Notes in Computer Science 5967) Berlin, Heidelberg: Springer. 182-196. doi:10.1007/978-3-642-12397-9_15.

Seyfeddinipur, Mandana 2006. Disfluency: Interrupting Speech and Gesture. (MPI Series in Psycholinguistics 39) Nijmegen: Max Planck Institute.

Szabó Éva 2020. A nyelvi agresszió megjelenése a politikai vitaműsorokban. Argumentum 16:31-43. doi:10.34103/ARGUMENTUM/2020/3.

Tóth Csilla 2011. Tekintetmintázatok és funkcióik a HuComTech-projekt céljainak tükrében. In Németh T. Enikő (szerk.) Ember-gép kapcsolat. A multimodális ember-gép kommunikáció modellezésének alapjai. (Segédkönyvek a nyelvészet tanulmányozásához 133) Budapest: Tinta Könyvkiadó. 101-118. 


\section{Függelék}

A példákban használt konverzációelemzési konvenciók (Jefferson 2004):

(.) mikropauza; nagyon rövid szünet, körülbelül egy szótagnyi hosszúságú

(2.0) megmért szünet (másodperc.tizedmásodperc)

[nem a bal oldali zárójel az átfedés kezdetét jelzi

[persze

nem] a jobb oldali zárójel az átfedés végét jelzi

persze]

= $\quad$ egyenlőségjel kapcsolja össze ugyanazon beszélő folyamatos

megnyilatkozásának részeit, ha azokat a másik beszélő közbeszólása miatt az átírásban el kell szakítani egymástól; egyenlőségjel jelöli azt is, ha két megnyilatkozás között nincsen intervallum, de átfedés sincs.

.h lélegzetvétel

.hh hangosabb, hosszabb lélegzetvétel

( ) érthetetlen közlést jelöl

aha, a vessző a szó végén emelkedő intonációt jelez

aha. a pont a szó végén eső intonációt jelez, amely nem minden esetben esik egybe a megnyilatkozás végével.

AHA a nagybetűvel való kiemelés a hangerő növekedését jelzi

a:ha a kettőspont a magánhangzó megnyúlását jelzi

- $\quad$ a kötőjel a megszakítás jele

((torokköszörülés))

a kettős zárójel a nem nyelvi hangjelenségeket jelzi

$>$ aha< a jel két eleme közé eső beszédszakasz tempója gyorsabb

<aha> a jel két eleme közé eső beszédszakasz tempója lassabb

\section{A szerzőkről}

Szabó Éva a Szegedi Tudományegyetem Nyelvtudományi Doktori Iskola Elméleti Nyelvészet Programjának hallgatója, az MTA-DE-SZTE Elméleti Nyelvészeti Kutatócsoport tudományos segédmunkatársa. Kutatási területe a pragmatika és a diskurzuselemzés, azon belül elsősorban a benyomáskeltés és a politikai nyelvhasználat.

Elérhetősége: szaboevi@hung.u-szeged.hu

Béres Tamara a Szegedi Tudományegyetem elméleti nyelvészet mesterszakán pragmatika szakirányon végzett. Kutatási területe a verbális agresszió megjelenése a magyar közösségi médiában.

Elérhetősége: tamiberes@gmail.com

Guba Csenge a Szegedi Tudományegyetem elméleti nyelvészet mesterszakos hallgatója számítógépes nyelvészet szakirányon. Szakdolgozatában egy beszélt nyelvi korpusz feldolgozásával és elemzésével foglalkozik.

Elérhetősége: csenge.guba@gmail.com 